\title{
What Do Jade Eggs Tell Us about the Category "Esotericism"? Spirituality, Neoliberalism, Secrecy, and Commodities
}

\author{
Susannah Crockford
}

While the literature on esoteric texts from antiquity through to the contemporary era is growing, there has been comparatively little written so far about material objects in esotericism and the economic conditions in which they are embedded. The products of contemporary spirituality are a starting point in this chapter, used to interrogate characterizations of the "commodification" of spirituality in neoliberalism, and the consequences this has for definitions of the category "esotericism." Focusing on scholarly arguments that esotericism is characterized by secrecy and rejected knowledge, I question how this applies in the context of global spirituality. Sociological theories of secrecy suggest how secrecy operates to enhance elite claims to power and elevated status. In the context of neoliberalism, claims to secrecy can be leveraged to make substantial profits. Previous definitions of esotericism have occluded this aspect of spirituality because they have failed to reckon with the power relations and economic relations in the field. By examining the material products through which contemporary esotericism has been commodified, the elitism inherent in the category is made overt.

An Introduction to Wellness, Goop-Style

Wellness products may seem to have little to do with esotericism at first glance, yet they are marketed with claims to secrecy and knowledge rejected by medical and scientific establishments. An emblematic example is the jade egg promulgated and-briefly-sold by the lifestyle company, Goop. The company was founded by the American actor and entrepreneur, Gwyneth Paltrow, and purveys a range of luxury clothing items, furniture, and wellness products online and through an email newsletter, as well as through a select number of boutiques in expensive locations in New York, Los Angeles, London, Toronto, and New England. There is a subsection "spirituality" on the website under the category "wellness," with an "ancient modality" tag for certain items. One such item was the jade egg, also available in rose quartz. The eggs were first recommended by one of Goop's "featured experts" (habitually representatives of 
alternative or naturopathic medicine), Shiva Rose. Rose called the jade eggs "the strictly guarded secret of Chinese royalty in antiquity," used by queens and concubines to help their relationships with emperors. ${ }^{1}$ Through harnessing the power of energy work and crystal healing, and through insertion in the vagina, the egg would clear the energy of the wearer, providing a spiritual cleanse. It would also strengthen the muscles and increase the sensitivity of the vagina, cultivating sexual energy, intensifying femininity, invigorating life force, and clearing qi pathways. The specific type of crystal used was nephrite jade, to which Rose attributed the ability to take away negative energy. It was a substance with great spiritual power in "many traditions." Shiva Rose offered an "incredible, secret practice that benefited everybody," that was used in "Chinese temples" but kept secret for "eons" by the Chinese royal family.

The eggs were soon made available for purchase on the Goop website, advertised with the extra benefit of hormone balancing. ${ }^{2}$ The reaction from Goop's consumers was swift: the eggs sold out within days. The reaction from the medical and legal establishments followed at a slower pace, with a lawsuit for false advertising and making medical claims without a license launched, eventually rendering a $\$ 145$,ooo fine and the eggs' withdrawal from sale by Goop. ${ }^{3}$ They are still available from other merchants, and Goop's own doctors

1 The article originally appeared as "Better sex: jade eggs for your yoni," Goop, https:// goop.com/wellness/sexual-heidh/better-sex-jade-eggs-for-your-yoni/ but has since been removed from the website. At the time of writing it is still available via the WayBackMachine, url: https://web.archive.org/web/20190718173851/https:/goop.com/wellness/ sexual-heidh/better-sex-jade-eggs-for-your-yoni/.

2 They remain advertised but not available to buy here https://shop.goop.com/shop/products/ jade-egg.

3 The lawsuit and settlement were reported widely in the media at the time. See Julia Belluz, "Let's call Gwyneth Paltrow's jade eggs for vaginas what they are: Goopshit," Vox 25 January 2017, https://www.vox.com/policy-and-politics/2017/1/23/14352904/gwyneth-paltrow-jade -eggs; Julia Belluz, "Goop was fined $\$ 145,000$ for its claims about jade eggs for vaginas. It's still selling them," Vox 6 September 2018, https://www.vox.com/2018/9/6/17826924/ goop-yoni-egg-gwyneth-paltrow-settlement; Kristine Phillips, "No, Gwyneth Paltrow, women should not put jade eggs in their vaginas, gynecologist says," Washington Post 22 January 2017, https://www.washingtonpost.com/news/to-your-health/wp/2017/o1/22/no -gwyneth-paltrow-women-should-not-put-jade-eggs-in-their-vaginas-gynecologist-says/

American gynaecologist and medical blogger, Jen Gunter, wrote against the use of jade eggs from a medical perspective, "Dear Gwyneth Paltrow, I'm a GYN and your vaginal jade eggs are a bad idea," 17 January 2017, https://drjengunter.com/2017/o1/17/dear -gwyneth-paltrow-im-a-gyn-and-your-vaginal-jade-eggs-are-a-bad-idea/ Gunter argued that the hormone balancing claim is biologically impossible, "Gwyneth Paltrow and GOOP still want you to put a jade egg in your vagina. It's still a bad idea," 11 May 2017 https://drjengunter.com/2017/05/11/gwyneth-paltrows-jade-eggs-again/, she calls believing 
wrote about jade eggs defending their business as standing up for marginalized women and their chronic health problems by providing information without judgment. ${ }^{4}$ In the parlance of conspiracy theory, they were "just asking questions." ${ }^{5}$

The message of Goop is that there is a way to perfect oneself. By using the right products, it is possible to curate the perfect neoliberal self: energized, tight, fashionable, radiant, glowing. ${ }^{6}$ It does, however, require plenty of money to access this route to perfection, as Goop sells primarily luxury fashion and accessories. The jade eggs were sold for $\$ 66$ a piece. Goop has grown from a free email newsletter to a $\$ 25$ o million business, part of the $\$ 4.2$ trillion global wellness industry. ${ }^{7}$ Goop is not alone in offering a series of products, opaque in purpose and complexity, invoking grand visions of personal enhancement. The wellness industry both fuels and profits from the idea that physical beauty is proof of inner righteousness as well as health. Those perfect on the outside are assumed to be equally perfect inside. In a capitalist society, those that are able to afford this level of purchasable perfection are the wealthiest. There is, therefore, a strong vein of classism and elitism running through not only Goop but the ideology of wellness that informs the industry.

in the efficacy of jade a form of believing in magic. Gunter also searched online archives of Chinese antiquities and found no evidence of jade eggs used by the royal family, Elfy Scott, "No Goop, jade vaginal eggs are probably not a 'strictly-guarded secret' from Ancient China," Buzzfeed News 3o October 2018, https://www.buzzfeed.com/elfyscott/a-researcher-looked -at-5ooo-jade-objects-to-prove-vagina.

4 "Uncensored: A word from our contributing doctors," Goop, https:/goop.com/wellness/ health/uncensored-a-word-from-our-doctors/.

5 Interestingly, Alex Jones, host of Infowars and talk radio DJ infamous for spreading conspiracy theories, also sells wellness products and supplements similar to those available from Goop, and the majority of the company's profits seem to derive from this source despite being more well known for the sensationalist content on their website. Seth Brown, "Alex Jones's media empire is a machine built to sell snake-oil diet supplements," New York Magazine 4 May 2017, http://nymag.com/intelligencer/2017/o5/how-does-alex-jones-make -money.html. On conspiracy theories and their relationship to New Age see Robertson 2016.

6 For a first person account of using Goop's products see Amanda Mill, "I gooped myself," The Atlantic 26 August 2019, https://www.theatlantic.com/health/archive/2019/o8/what-goop -really-sells-women/596773/.

7 The market value estimate is from the annual report of the Global Wellness Institute, https:/globalwellnessinstitute.org/press-room/statistics-and-facts/; On the growth of Goop as a business see Taffy Brodesser-Akner, "How Goop's haters made Gwyneth Paltrow's company worth \$25o Million," New York Times Magazine 25 July 2018, https://www.nytimes.com/ 2018/o7/25/magazine/big-business-gwyneth-paltrow-wellness.html and Olga Khazan, "The baffling rise of Goop," The Atlantic 12 September 2017, https://www.theatlantic.com/health/ archive/2017/og/goop-popularity/539064/. 
Wellness is an unregulated industry that capitalizes on people's desperation and insecurities, offering them cures for all ills and imperfections at high prices. Yet there is more to it than that, as wellness is the latest iteration of what has been known for some time as naturopathic or alternative medicine. The idea that Western biomedicine does not have the answer to every health problem is neither new nor particularly problematic (Baer, 2001). Naturopathic medicine is part of a wider current with many metaphysical, spiritual, and religious associations, informed by New Thought which emerged in America in the nineteenth century (Albanese, 2006, p. 395-421). It fits within the broad field of contemporary religious practice that is variously called the New Age Movement, New Age spirituality, or alternative spiritualities (Sutcliffe, 2002; Heelas, 1996; 2008; Heelas et al., 2005; Hanegraaff, 1996; Campion, 2016; Pike, 2004; Melton, 2007; Hammer, 2004, 2005; Partridge, 2004). Having studied this field for the past ten years, and completed two years of ethnographic fieldwork in the "New Age Mecca" Sedona, I prefer to simply use the term spirituality. ${ }^{8}$ Healing modalities involving crystals, energy work, multiple vaguely referenced "ancient" or "indigenous" traditions were a vibrant and easily visible part of the spiritual scene in Sedona, and the wider networks of spirituality that stretch globally. Many benefits, spiritual and physical, were claimed, some of which were unverifiable, but which nonetheless seemed to help people even if the scientific basis was scant.

Jade eggs with $q i$ boosting power would be seen as part of the range of acceptable and accepted claims in this milieu. Crystals, in particular, proliferated as part of healing practices, with different crystals attributed various properties such as clearing negative energy, enhancing meditative practice, or realigning chakras (see also Bartolini et al., 2013; Kyle, 1995). What any particular crystal did was an open, protean value, with the general assumption being that they had many special qualities and so any specific attribute was often left to personal interpretation and experience. One of my interlocutors in Sedona told me that she used one of her oblong crystals as a vibrator, since it was much better for the flow of her sexual energy than plastic. Within this milieu, jade eggs would not be cast out for being risible and dangerous, as they were in the media, legal courts, and medical opinion.

8 "New Age Mecca" is from Ivakhiv 2001, p. 147; for a substantive discussion of spirituality in Sedona and a working definition of spirituality, see Crockford 2017, 2018, 2019; on the term "spirituality" as a recent cultural category for what was once called New Age, see Huss 2014. 
Yet what does the alliance, embodied in jade eggs, between alternative healing modalities and the high-priced wellness retail industry indicate? The concurrence of the emergence of spirituality with the expansion of neoliberal capitalism has been noted by scholars (Huss, 2014; Redden, 2016; Heelas, 2008, p. 151-164; Possamai, 2003; LoRusso, 2017). Both emerged in North America and Western Europe during the 1970s to 1980s, sprouting up from the same socioeconomic context. The term "neoliberalism" is often used in as much of a vague, woolly, and diffuse way as spirituality is; however, a number of authors have given the term specificity. Loïc Wacquant (2009) set out a clear definition of neoliberalism as a specific set of policies that have been enacted by, or imposed on, governments globally. Deregulation, financialization, the expansion of mass incarceration, and the cultural trope of individual responsibility all characterized neoliberalism in Wacquant's account of the inequities this system caused, with the poor continually impinged, exploited, and incarcerated for the benefit of the wealthy. David Harvey (2005) sought to link neoliberalism to a specific state formation, and highlighted privatization, financialization, and deregulation as the economic policies that such states pursued. Aihwa Ong (2006) focused on neoliberalism as a form of governmentality, a network of power relations that created unequal access to freedom of movement, with capital and some types of citizen able to move freely, and others restricted behind borders.

Spirituality shares certain structural features with those outlined by political economic analyses of neoliberalism. It is a deregulated religion, with no central authority or creed or scripture determining orthodoxy and no priestly caste enforcing it. It is privatized-based on personal interior experience and beholden upon persons to determine for themselves-and part of the wider trend that José Casanova (1994) has named the privatization of religion. Financialization is the conversion of anything into capital: everything is for sale on the free market. Spirituality has been likened to a marketplace of religion (Redden, 2005), where beliefs and practices from any cultural or historical source are available for use and then resale to support spiritual practitioners who lack a supporting congregation or institutional body to pay for them as specialists. The cultural trope of individualism is very strong in spirituality also, where the route to spiritual development is considered to be up to the individual to discern and follow, and all other ties, including jobs, family, and homes can be forsaken in the pursuit of enlightenment.

There is one further value of neoliberalism to be considered, namely that of transparency. The neoliberal ideal is transparent governance (Mahmud, 2013, 
p. 19o). Freely available, reliable information about public and private business is seen as necessary for the functioning of the free market, to which all other ideals are subservient. Yet conspiracy and secrecy remain rife within neoliberal governance zones, despite supranational bodies like the International Monetary Fund enforcing transparency through anti-corruption requirements in exchange for debts and loans (Sanders and West, 2003, pp. 7-10). The dialectic of secrecy and transparency, concealment and revelation is another thread running through spirituality, one which connects it to the long history of currents that have been named esotericism.

Spirituality as Esotericism

To what extent spirituality is a form of esotericism, and whether this is a useful framing, depends of course on how esotericism is defined. In an early theorization of esotericism, Antoine Faivre drew an explicit boundary between esotericism proper and New Age, which he considered the province of studies of New Religious Movements (1994, p. 17). Wouter Hanegraaff defined what he called New Age religion as a form of secularized esotericism, because unlike previous currents of esotericism its "popular western culture criticism" emerged in a secularized rather than enchanted worldview (1996, pp. 520-521). Olav Hammer (2004, pp. $76^{-77}$ ) located New Age as the latest in a historical current of esoteric positions, and provided a useful nine point characterization of it. The work of Hanegraaff and Hammer brought spirituality into esotericism research in a way that Faivre initially avoided.

At which point we have arrived at the core issue: what is esotericism anyway? Much of the work of what Hanegraaff labels the second generation of esotericism studies has been to overturn the religionist paradigms that went before (Hanegraaff, 2016, p. 167). In this mostly historically focused research, esotericism has tended to be defined in oppositional terms, as a "counter" to mainstream knowledge or discourse. In what is perhaps currently the most widely used definition of esotericism, it is a form of rejected knowledge that formed part of how modern identity has been constructed; indeed the "polemical Other of modernity" (Hanegraaff, 2012, p. 374). It is an alternative that remains attractive to those wishing to reject the dominant rationalism of the Enlightenment, for example as Romanticism took as positive what the Enlightenment saw as negative. This is, naturally, a simplification, but the binary of mainstream/alternative reoccurs throughout current definitions of esotericism, as with Hanegraaff's labelling of spirituality as a form of popular western culture criticism. This defines spirituality, which he called "New Age religion," 
as first of all popular, with which Hanegraaff seems to mean something like a mass as opposed to elite phenomenon, or perhaps more simply that many people seem to like it. Secondly, it is "western"-although the boundaries of this historical-geographical-cultural construction remain unclear, since Hanegraaff uses the term in an under-calibrated way (cf. Strube, 2021). Finally, it is as a form of criticism-New Age is against whatever is dominant, mainstream, or supported by epistemic authorities. At the same time, Hanegraaff accepts that the label "esoteric" has become, in contemporary esotericism, a "desired commodity" (2012, p. 360). As discussed in more detail in Egil Asprem's chapter in this volume, this points to the power of being "alternative" or "rejected," that claiming out-group status can be valuable in some contexts.

The idea that what they are selling has been rejected by the dominant, mainstream powers that be was creatively deployed in the marketing of the jade egg, and in Goop's response to the backlash by said powers. The company's staff doctors claimed to be simply providing information, and countered that doctors and lawyers who complained about the lack of empirical basis of that information were marginalizing women and their choices. There is, as Asprem (2021) also suggests, ambiguous politics layered beneath adopting positions of rejected or alternative knowledge. What is the mainstream here? The medical and legal authorities objecting to crystals as a healing modality? Or the multimillion-dollar valued corporation run by a movie star? I set up this opposition intentionally-what is mainstream and what is rejected, what is dominant and what is alternative, what is orthodox and what is esoteric-is neither an obvious nor a neutral categorization. It is also not a stable or fixed position. The boundaries of mainstream/alternative shift and are contingent on the historical period and cultural context. Much like the term "western," esotericism is a politically and economically mediated category and scholars have to deal with these implications.

Claims to being marginalized or rejected by an ambiguously identified mainstream or dominant position are a common component in discourses of secrecy. The secret of the jade egg was kept by the elites for "eons," and now that secret can be revealed-even if "they" do not want you to know about it. Secrecy grants a form of social power. Hugh Urban (2001) employs the sociological works of Georg Simmel (1950, pp. 307-315) and Pierre Bourdieu (1984) to call secrecy an adornment that can grant forms of capital. In the formation of Scottish Rite Freemasonry in post-Civil War America-a period of intense social change, economic growth, industrialization, and urbanization-the secrecy of the clubs helped white middle-class European-descended Protestant males maintain their status. Lodges were conservative, elitist, and respectable, 
enabling the maintenance of socioeconomic power through the exclusion of others. What went on at the clubs was not nearly so important as who was and who was not allowed in.

Urban argues that the prevalence of secrecy warrants a theoretical shift in the scholarly approach to esotericism because the content of the secret is often unknowable, or once known, not permissible to transmit to the uninitiated, something he calls the "double bind" of secrecy (1998, p. 212). Identifying another period of upheaval and transition in colonial Bengal, Urban suggests the Kartābhajās, a group in the Vaiṣnava-Sahajiyā Tantric tradition, gained new forms of power, status, prestige, and identity through secrecy. An elaborate ritual language that seemed nonsensical to the uninitiated allowed the group to imply that they held powerful and valuable secrets. Although the comparison is inexact-unlike American Freemasons the Kartābhajās were low caste and denied economic and symbolic wealth in Indian society both before and during British colonial rule-in both contexts secret societies allowed for the development of social and economic capital through membership. Urban's comparative approach articulates two different kinds of secrecy dynamic: a social function that builds cohesion and elevates the status of a group and a rhetoric of secrecy attached to content both when it is unknowable and well known. Delineating some structural features of secrecy grants the potential to use it as a concept for identifying esotericism across different geographical and historical contexts.

The significance of secrecy, for Urban, is how it operates to grant value to certain forms of knowledge, so that possession of secret knowledge is beneficial in social and political terms to the bearer. A similar position is adopted by Kocku von Stuckrad, who argues that esotericism is a discourse characterized by secrecy and structured by a dialectic of concealment and revelation (2010, p. 243). Secrecy grants social capital, in Bourdieu's sense, because it grants a superior position on the field through knowing something which cannot be shared freely. It is elitist, superior and exclusive, and can also be translated into economic capital. When speaking of the jade egg, this approach seems to fit the claims to a certain extent: buying it is a way of buying in to the secret it embodies and it is only available to those that can afford it. But here a neoliberal economist could argue that it is therefore "freely" available because it is available on the free market, and all citizens in the marketplace are free to sell their labor in exchange for a wage that they can spend on consumer objects as they wish. Jade eggs are not limited to a specific sector of the population nor do they require initiation into a certain organization. It is a commodity. 
When thinking through the dialectic of concealment and revelation that both von Stuckrad and Urban emphasize, what does the jade egg reveal? It is the object of revelation, a secret concealed by Chinese royalty to be disclosed by Shiva Rose through the medium of Goop. The actions required to learn of its content are reading the Goop website and paying money in its webstore. It is marketed to consumers, but not all consumers equally. It is aimed at affluent, anglophone women (the webstore is in English even when set to deliver in Germany or Italy). The market is women who are likely to be older, postchildbirth, and concerned with their social status as well as their physical, sexual and emotional health. Buying the jade egg is not simply a case of purchasing a product. It also buys into the idea, backed by a holistic worldview and claims to secret, ancient knowledge, that such an object is efficacious.

As some scholars have noted (e.g. Hanegraaff, 2016, pp. 163-164), secrecy is not unique to esotericism. This, however, does not mean that secrecy should be excluded as a defining characteristic of the category. The status of being rejected or polemically marginalized is not the sole preserve of esoteric currents, either. Arguably, there are far more systemic marginalizations (along the lines of gender, race, class...) that went into the constitution of "western modernity." What marks esotericism is perhaps the conjunction of the two: a current that clouds itself in obscurity and at the same time has been rejected or marginalized by what is perceived as a more dominant cultural force. Secrecy operates as a basis around which social groups form, mitigating harm through veiling authorship of controversial texts or enrollment in socially questionable clubs (Debenport, 2019). It has been a tenet in social scientific treatments of secrecy, since Simmel, that it is not the content of the secret but its context and functions that matter. This is not to disregard the content, but to acknowledge, as Urban does, that it may be unknowable or untransmittable, and moreover, to understand that the power of the secret in society depends on the conditions of its production and its authorship. ${ }^{9}$

With the specificity of context, secrecy creates value, and its possession excludes outsiders and includes insiders (Jones, 2014, pp. 54-55). It is this dy-

9 To illustrate with an example: If I told you that a woman in her sixties living in New York State deleted thousands of old emails, you would rightly treat the disclosure of this secret with the banality it warrants. With the context that this specific woman was Hillary Rodham Clinton, former senator and presidential candidate, and the disclosure occurred three days prior to the US presidential election in 2016, coming from the mouth of the FBI director, this secret gains the power to shift the course of global geopolitical events. 
namic, I argue, that is fundamental to esotericism, and what makes the category inherently elitist. Secrets need to be performed in public to be powerful, they must be known to exist. They are concealed to most, disclosed to only a chosen few, and there is power-and capital-in being one of the chosen. Initiatory secrets in particular have a sense of spectacle, being known by many yet only few have the authority to disclose their content-a form of "public secret" (Taussig, 1999). This is illustrated by Lilith Mahmud's (2013) ethnography of Freemasonry in contemporary Italy. Despite being "profane," meaning not initiated into a Masonic lodge and therefore not allowed to know of the content of their rites, Mahmud found that her Masonic interlocutors were happy to discuss their rites and practices after developing friendships with her. The content of lodge rituals was indeed long known to the public because they had been exposed by disgruntled former members and through the media. Even so, Mahmud was not focused on the content of the secret rituals but on how the members of lodges she came to know leveraged their elite positions and relationships to negotiate their status in a society that had become hostile to right wing secret societies. Her characterization of Masonic knowledge production illuminates the production of knowledge in esotericism more widely: "The secret was always in front of our eyes, but it is only in hindsight that we can understand it" (2013, p. 201).

Secrecy as a marker of group identity has been observed by anthropologists in initiatory rituals cross-culturally (Stewart and Strathern, 2014, p. 79). The exegesis of such rituals may not mean the same to specialists and ordinary participants, and certain aspects can be revealed to some but hidden to others. Tanya Luhrmann (1989) applies the anthropological lens to ritual magic in England, remarking that it gave the middle-class professionals a way to better handle their emotions and behavior. The effects of the rituals had a psychological benefit, even if magic could not be scientifically verified. It granted a sense of control over events, elevating the practitioner to a privileged position even if only in their own estimation. This is close to the argument Goop's doctors made in favor of the jade egg. It was not an argument of verifiability in a scientific sense but of psychological and emotional efficacy: putting women in control of their bodies through an object they found useful, even if experts scoffed.

But why should middle-class practitioners of ritual magic, or middle-class practitioners of crystal healing, strive for a sense of control and power? A sense of exclusion can be met with a reassertion of value through inclusion in an alternate group. A woman who feels her symptoms or feelings are not countenanced by conventional medicine can turn to naturopathic medicine. Anxiety increased in neoliberal economies as the middle class shrank. As economic 
inequality was exacerbated through neoliberal policies that shifted more of the wealth to ever smaller proportions of the population, and real wages remained stagnant, middle class status became harder to maintain (Harvey, 2005, pp. 35-38). Casualization of contracts increased insecurity, as withdrawal of social provision snipped the safety net of welfare states, making the consequences of downward social mobility more devastating. Under neoliberalism, those who manage to remain middle class have much to be anxious about, and material reasons to desire power and control over their lives. Spirituality then becomes a way out of one status, perceived as slipping or failing, through claiming a different status.

The doubleness of secrecy as both known and unknown enhances the value of an alternative status or group membership. This is exemplified by the book, The Secret (2006). Despite its name, it is one of the most well-known and bestselling books in English language publishing in the last thirty years, now in its tenth edition. It promises a secret of great value: that you, the individual, are in control of your own reality. This is one of the core tenets of spirituality more widely: each person creates their own reality. The Secret offers New Thought-inspired affirmations as a way of manifesting abundance, meaning prosperity, money, good health, whatever one values as worth creating. This is a religious formulation of the cultural trope of individual responsibility in neoliberalism. The poor are responsible and also deserving of their poverty, and the wealthy earn their riches. This abnegates the influence of social structure to the extent that it exacerbates class politics. Secrecy is indeed an important strand of class politics. Obscuring what occurs among, how to act in, or move into higher classes, enables elites to exacerbate divisions among the working and middle classes. The working classes suspect that there are secret cabals making decisions they are not privy to and that do not benefit their interests (Sanders and West, 2003, pp. 11-12).

Secrecy and concealment provide not only the sense of control over one's own self, they also offer a route to control others through demarcation of ingroups and out-groups. As Urban suggests for both post-Civil War America and colonial Bengal, secrecy and membership of secret groups can offer a means to hold onto socioeconomic status, or claim it when it is denied. There is an important aspect of esotericism that is about power, and more specifically attempts to attain, maintain or retain elite status. Secrecy is part of how elitism is produced, this is Simmel's power of the secret. In secret societies, the point is to claim there is a secret, not to reveal the secret nor to keep its very existence hidden. The existence of the secret needs to be revealed, but its content limited to the initiated. The power is in having it and claiming that most other people do not know it, and are therefore inferior because of this lack of 
knowledge. Who is keeping the secret and for what reason? What group can be formed around the secret? What is the cost of access to the secret? These are important questions to ask of any esoteric currents.

Yet such questions are often left unasked, or relegated to the status of discourse. The academic study of esotericism, coming as it does from intellectual history, all too often revolves around texts of white Western European male authors, a canon that excludes even as it makes claims to being excluded (Bakker, 2019). Defining esotericism as only rejected, hidden, or secret knowledge, without examining what such claims do-socially, economic, politically-obscures the implied power relations. Scholars then run the risk of defining esotericism as practitioners of esotericism would want to be defined, as if they really did have a secret. Certain esoteric currents may be rejected but perhaps what is more important, in socioeconomic and political terms, is that they are not universally rejected. A group or form of knowledge or practice that is rejected by some, but not by others, gives those who adopt it a new way of defining their identity. Through joining a secret group, members are acquiring social and economic capital, in contrast to and often antagonism with those that might or do reject them. Spirituality is not rejected by many, but it is rejected by some and that enhances its reputation to those to whom it appeals. The internal differentiation of marginalized groups or discourses creates social hierarchies, an example of "credibility mobility" (Asprem, forthcoming, pp. 22-25).

Commodities and Commodification of Spirituality, a Brief Conclusion

Spirituality and its overt and obvious links to neoliberalism lead to it being cast aside as "commodified," devalued as trivial or insignificant because it incorporates consumerism (Redden, 2016). Commodification of religion has been treated with a certain suspicion in historical studies, yet the exchange of commodities for profit has played a role in many different types of religion historically and cross-culturally. Esotericism studies tend towards a certain idealism, or at least, an elevation of ideas and the texts that encode them over objects, commodities, and material conditions. This is partly because the materiality of esotericism is harder to find in historical sources, texts, and so on. Yet objects can enact the same strategy of secrecy as esoteric texts-this is a powerful object, its power is secret, only the initiated elite may access it. Spirituality is replete with objects imbued with special properties, such as crystals, that can be sold and are expected to be sold. It is also possible to construct a whole spiritual path around buying and selling and meditating with crystals. Their flow 
as commodities does not cancel out their spiritual value. Esotericism looks different when looking at it ethnographically, sociologically, at people living and enacting it now, as opposed to sifting through textual sources (Crockford and Asprem, 2018).

It is much easier to see the elitism of esotericism in the exchange of commodities that also grant spiritual power-it is overt. The most spiritually potent crystals are often the most expensive ones, such as crystal skulls which are sold for thousands of dollars. It is also easier to see the emptiness of the secret. There is often an aura of authenticity that cloaks historical sources, particularly the more ancient ones. But a jade egg can be bought and tested, the value dependent on the ascription of its purchaser more obvious, and its claims to efficacy can be subject to legal challenges. The self-affirming nature of much of spirituality means that it does not matter so much if its objects are efficacious, it matters if people buy it, talk about it, and use it. The secrecy makes them feel like it is worth trying: get in on the secret, into the club, become one of the insiders, the initiated, the elect.

Esotericism as a system of knowledge production has a particular history, and the claims to knowledge are based on the origin of that knowledge being in some way concealed from most eyes-hidden, rejected, secret, and so on. The definitions of the category of esotericism need to be pushed further, to examine the social and economic positions and power relations involved. Who rejects it and who does not? Who benefits from adopting a secret tradition? What does the secret do, in other words? A secret is a way of creating value, and value has no essence, no content, no subjectivity. Value is a magical power, the process of assigning something from nothing (Graeber, 2011, p. 246). This must be hidden, made secret, or else its facade will fall, like the Wizard of Oz. Esotericism is an inherently elitist system of knowledge production, intended for the few, the initiated, the elect, with the power and knowledge to glimpse what must be hidden. But in the end, the secret is that there is no secret.

\section{Bibliography}

Albanese, C.L. (2006) A Republic of Mind and Spirit: A Cultural History of American Metaphysical Religion. New Haven: Yale University Press.

Asprem, E. (2021) "Rejected Knowledge Reconsidered: Some Methodological Notes on Esotericism and Marginality," in Asprem, E. and Strube, J. (eds.) New Approaches to the Study of Esotericism. Leiden and Boston: Brill, pp. 127-146.

Asprem, E. (forthcoming) "On the Social Organisation of Rejected Knowledge: Reassessing the Sociology of the Occult," in Hedenborg White, M. and Rudbøg, T. 
(eds.) Western Esotericism and Deviance: Proceedings of the Sixth International Conference of the European Society for the Study of Western Esotericism. Leiden: Brill, pp. $1-36$ [Author's pre-print].

Baer, H.A. (2001) "The Sociopolitical Status of U.S. Naturopathy at the Dawn of the 21st Century," Medical Anthropology Quarterly, 15(3), pp. 329-346. [Online] DoI: 10.1525/ maq.2001.15·3.329.

Bakker, J.M. (2019) "Hidden Presence: Race and/in the History, Construct, and Study of Western Esotericism," Religion, pp. 1-25. [Online] DOI: 10.1080/0048721X.2019 .1642262 .

Bartolini, N. et al. (2013) "Psychics, Crystals, Candles and Cauldrons: Alternative Spiritualities and the Question of Their Esoteric Economies," Social \& Cultural Geography, 14(4), pp. 367-388.

Bourdieu, P. (1984) Distinction: A Social Critique of the Judgement of Taste. London: Routledge.

Byrne, R. (2006) The Secret. New York: Atria Books/Beyond Worlds.

Campion, N. (2016) The New Age in the Modern West: Counterculture, Utopia and Prophecy from the Late Eighteenth Century to the Present Day. London: Bloomsbury Academic.

Casanova, J. (1994) Public Religions in the Modern World. Chicago: University of Chicago Press.

Crockford, S. (2017) After the American Dream: The Political Economy of Spirituality in Northern Arizona. Unpublished PhD thesis. London School of Economics and Political Sciences.

Crockford, S. (2018) "A Mercury Retrograde Kind of Day: Exploring Astrology in Contemporary New Age Spirituality and American Social Life," Correspondences, 6(1), pp. 47-75 [Online].

Crockford, S. (2019) "Becoming a Being of Pure Consciousness: Fasting and New Age Spirituality," Nova Religio, 23(1), pp. 38-59.

Crockford, S. and Asprem, E. (2018) "Ethnographies of the Esoteric: Introducing Anthropological Methods and Theories to the Study of Contemporary Esotericism," Correspondences, 6(1), pp. 1-23 [Online].

Debenport, E. (2019) "What is Secrecy and How Can We Understand Its Relation to Social Facts?," American Anthropologist, 121(1), pp. 201-204.

Faivre, A. (1994) Access to Western Esotericism. Albany: State University of New York Press.

Graeber, D. (2011) Debt: The First 5,00o Years. New York: Melville House.

Hammer, O. (2004) Claiming Knowledge: Strategies of Epistemology from Theosophy to the New Age. Leiden: Brill.

Hammer, O. (2005) "New Age and the Discursive Construction of Community," Journal of Alternative Spiritualities and New Age Studies, 1, pp. 111-127. 
Hanegraaff, W.J. (1996) New Age Religion and Western Culture: Esotericism in the Mirror of Secular Thought. Leiden: Brill.

Hanegraaff, W.J. (2012) Esotericism and the Academy: Rejected Knowledge in Western Culture. Cambridge: Cambridge University Press.

Hanegraaff, W.J. (2016) "Esotericism Theorized: Major Trends and Approaches to the Study of Esotericism," in DeConick, A. (ed.) Religion: Secret Religion. New York: Macmillan, pp. 155-170.

Harvey, D. (2005) A Brief History of Neoliberalism. Oxford: Oxford University Press.

Heelas, P. (1996) The New Age Movement: The Celebration of the Self and the Sacralization of Modernity. Oxford: Blackwell.

Heelas, P. (2008) Spiritualities of Life: New Age Romanticism and Consumptive Capitalism. Oxford: Blackwell.

Heelas, P. et al. (2005) The spiritual revolution: why religion is giving way to spirituality. Oxford: Wiley-Blackwell.

Huss, B. (2014) "Spirituality: The Emergence of a New Cultural Category and Its Challenge to the Religious and the Secular," Journal of Contemporary Religion, 29(1), pp. $47-6$ o.

Ivakhiv, A. (2001) Claiming Sacred Ground: Pilgrims and Politics at Glastonbury and Sedona. Bloomington: Indiana University Press.

Jones, G.M. (2014) “Secrecy," Annual Review of Anthropology, 43(1), pp. 53-69.

Kyle, R.G. (1995) The New Age Movement in American Culture. Lanham: University Press of America.

LoRusso, J.D. (2017) Spirituality, Corporate Culture, and American Business: The Neoliberal Ethic and the Spirit of Global Capital. London: Bloomsbury Academic.

Luhrmann, T.M. (1989) "The Magic of Secrecy," Ethos, 17(2), pp. 131-165.

Mahmud, L. (2013) "The Profane Ethnographer: Fieldwork with a Secretive Organisation," in Garsten, C. and Nyqvist, A. (eds) Organisational Anthropology: Doing Ethnography in and among Complex Organisations. London: Pluto Press, pp. 189-207.

Melton, J.G. (2007) "Beyond Millenialism: The New Age Transformed," in Kemp, D. and Lewis, J.R. (eds) Handbook of new age. Leiden: Brill, pp. 77-101.

Ong, A. (2006) Neoliberalism as Exception: Mutations in Citizenship and Sovereignty. Durham: Duke University Press.

Partridge, C. (2004) Re-Enchantment of the West: Alternative Spiritualities, Sacralisation, Popular Culture and Occulture. London: T\&T Clark.

Pike, S.M. (2004) New Age and Neopagan Religions in America. New York: Columbia University Press.

Possamai, A. (2003) "Alternative Spiritualities and the Cultural Logic of Late Capitalism," Culture and Religion, 4(1), pp. 31-43. 
Redden, G. (2005) “The New Age: Towards a Market Model," Journal of Contemporary Religion, $20(2)$, pp. 231-246.

Redden, G. (2016) "Revisiting the Spiritual Supermarket: Does the Commodification of Spirituality Necessarily Devalue It?," Culture and Religion, 17(2), pp. 231-249.

Robertson, D.G. (2016) UFOs, Conspiracy Theories and the New Age: Millennial Conspiracism. London: Bloomsbury.

Sanders, T. and West, H.G. (2003) "Power Revealed and Concealed in the New World Order," in West, H.G. and Sanders, T. (eds.) Transparency and Conspiracy: Ethnographies of Suspicion in the New World Order. Durham: Duke University Press, pp. 1-37.

Simmel, G. (1950) The Sociology of Georg Simmel. Translated by K.H. Wolff. Glencoe: The Free Press.

Stewart, P.J. and Strathern, A. (2014) Ritual: Key Concepts in Religion. London: Bloomsbury Academic.

Strube, J. (2021) "Towards the Study of Esotericism without the 'Western": Esotericism from the Perspective of a Global Religious History," in Asprem, E. and Strube, J. (eds.) New Approaches to the Study of Esotericism, Leiden and Boston: Brill, pp. $45^{-66 .}$

Sutcliffe, S. (2002) Children of the New Age: A History of Spiritual Practices. London: Routledge.

Taussig, M.T. (1999) Defacement: Public Secrecy and the Labor of the Negative. Stanford: Stanford University Press.

Urban, H.B. (1998) "The Torment of Secrecy: Ethical and Epistemological Problems in the Study of Esoteric Traditions," History of Religions, 37(3), pp. 209-248.

Urban, H.B. (2001) "The Adornment of Silence: Secrecy and Symbolic Power in American Freemasonry," Journal of Religion \& Society, 3, pp. 1-29.

Von Stuckrad, K. (2010) "Secrecy as Social Capital," in Kilcher, A.B. (ed.) Constructing Tradition: Means and Myths of Transmission in Western Esotericism. Leiden: Brill, pp. 239-253.

Wacquant, L.J.D. (2009) Punishing the Poor: The Neoliberal Government of Social Insecurity. Durham: Duke University Press. 